\title{
Doctoral theses on Laestadius and the Laestadian movement 1937-2018
}

$\mathrm{T}$ he scope of this review is all doctoral theses that exist on Laestadius and the Laestadian movement. A total of thirtyone doctoral theses on Laestadius and the Laestadian movement are included in this review. The Laestadian movement is an international one, albeit primarily established in the Nordic countries, Finland, Norway and Sweden. The review aims at presenting an overview of doctoral theses, countries where they are produced, academic disciplines that have contributed to this research, and finally to discuss some main tendencies.

\section{Introduction}

This review article aims at providing a general overview of the main tendencies in thirty-one doctoral theses that are identified as dealing with either Lars Levi Laestadius (1800-61) or the Laestadian movement. Laestadius and the Laestadian movement have generated interest amongst researchers in different academic fields, such as church history, theology, history, social anthropology, the study of religion, botany and philosophy (see Larsen in this volume). In addition, Laestadius and the Laestadian movement have gained critical interest from journalists and intellectuals; especially the moment when the Laestadian revival broke loose in the 1840 s (see Kristiansen in this volume). In total an enormous number of articles and books have been produced about Laestadius and the Laestadian movement; something several bibliographies bare witness to. ${ }^{1}$

This article is (limited to) a review of doctoral theses produced in the period from when the first thesis was delivered in 1937 to 2018 . The aim of the research is to analyse the main tendencies in the doctoral theses. The article is structured by reviewing firstly theses on Laestadius and secondly theses on the Laestadian movement. Concerning the theses on Laestadius, I will present which country they are from, and secondly, which parts of Laestadius's work they cover (theology/church history, [religious] philosophy, natural sciences, or folklore/mythology). In doing so, it becomes clear that it is his work as a priest that has been given most attention, while his work in the natural sciences is not covered in doctoral theses at all.

The theses on the Laestadian movement will also be mapped according to the country in which they are produced and secondly which period of the Laestadian movement they cover. This is to say, whether they

1 See bibliographies by Raittila (1967), Rydving (2000a), and Lindin and Rydving (2007: 159-79). 
cover the period before the big schism in the Laestadian movement in 1901 (18611900) or after (1901-2018). This is relevant because it will say something about which Laestadian groups are covered in the doctoral theses.

\section{Lars Levi Laestadius \\ and the Laestadian movement}

The Laestadian movement - also referred to as Laestadianism - can be described as a Christian revival movement that occurred as a result of the preaching of the Swedish minister Lars Levi Laestadius. The revival first erupted in Karesuando in the 1840s, on the border between Sweden and Finland, and within a couple of years also spread to Norway and other parts of Finland and Sweden. In the 1860 , migrants from Scandinavia also brought the Laestadian movement to the United States (Talonen 2001). At the end of the nineteenth and the beginning of the twentieth century, several internal conflicts arose, and the Laestadian movement divided into several groups. Today the main groups are the Firstborn $^{2}$ (Finland, Norway and Sweden), Laestadianernas Fridsföreningars Förbund r.f (LFF, Laestadian Federation of the Peace Associations) ${ }^{3}$ or Rauhan Sana (Word of

2 In 2015-16 the Firstborn group were divided in two in Finland. This division is discussed in Ollilainen's article in this volume.

3 LFF is an umbrella organization for nine member congregations in Finland located in Ostrobothnia, along the western coastline in Finland. In southern Finland, there are congregations in Helsinki. Rauhan Sana is a monthly bulletin in Finnish that has been also used as a name for the same Laestadian group. LFF and Rauhan Sana are sister congregations with the Norwegian Alta group, and belong to the same Laestadian tradition, sometimes referred to as 'Little Firstborn'.
Peace) (Finland, Norway and Sweden), Conservative Laestadianism ${ }^{4}$ (which primarily exists in Finland), New Awakening (primarily in Finland) and Lyngen group (which exists only in Norway). More groups could have been mentioned: in 2001, Jouko Talonen (2001: 53) counted eighteen different Laestadian groups. In general, the Laestadian groups can be characterized as centred on conservative Christian ideas, emphasising the Bible as the word of God, and highlighting the importance of the individual's belief in the forgiveness of sins in the name and blood of Jesus Christ. Laestadian groups are traditionally family oriented, sceptical of liberal theology, rejecting female and homosexual priests, and sceptical concerning the use of contraceptives. The large number of groups makes it important to stress that the Laestadian movement (or Laestadianism) is as diverse as any other religious tradition, which could be emphasised by writing the term(s) in plural - Laestadian movements (or Laestadianisms).

Laestadius himself was not a traditional minister in his time. He published academic works in botany and meteorology, and wrote several academic works in fields such as Sami mythology and religious philosophy; most of them, however, remained unpublished while he lived (see

4 The term 'Conservative Laestadianism' is in this article used in accordance with Finnish researchers. 'Conservative Laestadianism' is the group which historically is a part of the 'Old Laestadian' tradition and that relates to SRK (Suomen Rauhanyhdistysten Keskusyhdistys ry, the central organization of Conservative Laestadians) as their central office/organizational office, located in Oulu. Although the role of the SRK is essential in the context of Conservative Laestadianism, it cannot include or refer to the Conservative Laestadianism in its entirety. 
Rydving 2000a). In addition, he published his own monthly bulletin, Ens Ropandes Röst $i$ Öknen (The voice of one crying in the wilderness) in the period 1852 to 1854, wrote a lot of letters to scientists and church officials, and 466 of his sermons (in Finnish, Swedish and Sami) have been preserved (Elgvin 2010: 36).

\section{A discourse-inspired review}

This review is inspired by a discourseanalytical approach. A well-established idea in theory on discourse analysis is that a discursive approach provides a research perspective rather than a particular method (cf. Hjelm 2011; von Stuckrad 2014: 3). This article's basis in discourse analysis arises out of a perspective that academic research can be treated as a field of discursive practices. Thus, 'discourse' is understood as 'communicative structures that organize knowledge in a given community...' (von Stuckrad 2014: 11). ${ }^{5}$ Doctoral theses on Laestadius and the Laestadian movement are thus treated as expressions of how knowledge within this research area has been produced and organized. One of the focus areas of this article is to identify and discuss which academic disciplines have contributed to this research.

Inspired by a discourse-analytical approach, I will argue that it is helpful to review tendencies in doctoral theses on Laestadius and the Laestadian movement, because this kind of review contributes to

5 The full quote reads: 'Discourses are communicative structures that organize knowledge in a given community; they establish, stabilize, and legitimize systems of meaning and provide collectively shared orders of knowledge in an institutionalized social ensemble. Statements, utterances, and opinions about a specific topic, systematically organized and repeatedly observable, form a discourse' (von Stuckrad 2014: 11). the project of looking at the scholarly construction of Laestadius and the Laestadian movement and its discursive entanglements with other cultural systems and academic disciplines. However, a review that is limited to doctoral theses must be considered as one of several steps in order to get a broader picture of the research on Laestadius and the Laestadian movement.

\section{Doctoral theses as material for a systematic review}

A systematic review is a method of making sense of large bodies of information, and to identify where little or no research has been done and where new studies are needed (Petticrew and Roberts 2006: 2). Systematic reviews of doctoral theses have also been used to map tendencies within academic disciplines (such as history, see Amirell 2006; Ryymin et al. 2019). One should of course be aware that a review of doctoral theses does not provide the full picture of the research within a field. In Swedish historiographical research, researchers have pointed out that doctoral theses might be used as a 'rough indicator' of developments in historical research (Amirell 2006: 261). Thus, doctoral theses provide a starting point in order to map tendencies. Doing a review on doctoral theses in a 'limited' area also contributes to the process of selfreflection within the research on Laestadius and the Laestadian movement.

Doctoral theses are interesting because there are certain academic criteria they have to fulfil in order to be approved: they should be of a certain extent, bring in new knowledge about the field, be updated on other recent developments, and be able to refer to a data material that has been collected, analysed and discussed. A doctoral thesis is often definitive for an academic career. It is expected that the doctoral students place themselves within the field, and, one might 
presume that new theoretical insights and research trends are reflected in doctoral theses. Doctoral theses are (in most cases) also the work mainly by (relatively) young scholars at the start of their careers. One might also presume that the supervisors' and institutions' research interests and specialisations are reflected in the doctoral theses (Ryymin et al. 2019: 135).

Reviews are usually made within one academic discipline. Doctoral theses on Laestadius and the Laestadian movement are rooted in various academic disciplines. The work of this review has revealed that since the turn of the millennium, dissertations have been written within a number of different academic disciplines in addition to theology and church history - which are by far the dominating disciplines. Now there are theses in history, the study of religion, social anthropology and political science. Different disciplines offer somewhat different research questions and theoretical perspectives. Research within different academic disciplines are therefore most welcome.

\section{Mapping, reading and categorization of the theses}

In order to get an overview of all the doctoral theses dealing with the Laestadian movement or Lars Levi Laestadius, I have systematically read bibliographies in articles and books from all the Nordic countries. ${ }^{6}$ A great help in mapping early material

6 An exclusive focus on doctoral theses will necessarily have the result that other extensive books in other academic genres that are equal in quality and scope to doctoral dissertations, presenting highly relevant research on Laestadius and the Laestadian movement, are left out (such as Boreman 1953; Bjørklund 1985; Brännström 1990; Franzén 1973; Heith 2018; Thulin 1949 and Wikmark 1980). is Pekka Raittila's (1967) bibliography. I have also used my network of colleagues.

The criterion for including a thesis in this review has been that it deals extensively with the Laestadian movement. A result is that theses of Eetu Kejonen (2014), Marit Myrvoll (2011) and Nellejet Zorgdrager's (1989/97) are included in the review, while Lars Elenius's (2001) thesis in the history of modernisation, nationalism and language change in the Torne valley, is excluded. Elenius does bring attention to the Laestadian movement as an important factor in understanding the modernisation processes, and the complexity of ethnicity and language in the Torne valley.

A possible category in mapping theses could be a category of 'persons related to the Laestadian movement' (such as Auranen 2008; Mäkitalo 2016; Pohjanen 1979; Vuollo 2006). ${ }^{7}$ Theses in this category are biographical and include people with a background in the Laestadian movement. However, these theses do not say much about the Laestadian movement other than that it is the religious context or background of these persons. To what extent their Laestadian background has had an influence is a matter of interpretation. Thus, I have not included theses in this category in my review.

The review of the theses on the Laestadian movement are firstly structured according to the Nordic country in they were produced. Secondly, the theses are differentiated by their focus on Laestadius or the Laestadian movement. It is expedient to separate the theses on Laestadius from the theses on the Laestadian movement because the theses on Laestadius focus on

7 Thanks to Professor Jouko Talonen (University of Helsinki) for making me aware of these theses and introducing this category and challenging my review on this point. 
him as a person, his theology, or as a philosopher. The theses on Laestadius cover the time when he was alive, 1800-61. The theses on the Laestadian movement primarily focus on a period after Laestadius's death. There are some exceptions, but the theses on the Laestadian movement focus on aspects on Laestadianism as a Christian revival movement.

The theses on the Laestadian movement are divided according to whether they cover the early period of the Laestadian movement (1861-1900) or whether they are limited to a period after the major schism between eastern and western Laestadianism at the beginning of 1900 s. For theses that historically deal with the Laestadian movement in the twentieth century, it is of relevance to see which Laestadian group is covered in these theses. This might help detect whether there are Laestadian groups that have been subject to more research than others. This focus will help detect possible 'holes' in the research on the Laestadian movement and define a challenge for future research. The academic discipline in which the thesis is written will also be a subject for categorisation.

As illustrated in Figure 1, there are eight theses on Laestadius and twenty-three on the Laestadian movement. Twenty out of thirty-one theses establish Finland as the country in which most doctoral theses on

Figure 1. Theses on Laestadius and the Laestadian movement

\begin{tabular}{l|c|c|} 
& $\begin{array}{c}\text { Theses on } \\
\text { Laestadius }\end{array}$ & $\begin{array}{c}\text { Theses on the Laes- } \\
\text { tadian movement }\end{array}$ \\
\hline Finland & 5 & 15 \\
Norway & 0 & 5 \\
Sweden & 3 & 1 \\
$\begin{array}{l}\text { Other (US and the } \\
\text { Netherlands) }\end{array}$ & 0 & 2 \\
Total & 8 & 23
\end{tabular}

the subject have been produced. In Norway, there are five theses on the Laestadian movement, but none on Laestadius. In Sweden, there is only one doctoral thesis on the Laestadian movement, which is surprisingly little. However, three on Laestadius corrects the picture in some extent. Two doctoral theses are identified which come from outside the Nordic countries; in the Netherlands (Zorgdrager 1989/1997) and the United States (W. R. Juntunen 1988).

Most of the theses on the Laestadian movement include chapters about Laestadius. A couple of the theses could be placed in both categories. Martti E. Miettinen's (1942) thesis deals mostly with the time of Laestadius; still, Miettinen focuses on the background and context of the Laestadian movement. I have also found support for placing Miettinen's thesis in the category of theses on the Laestadian movement in Raittila's (1967: 294) bibliography.

While the dissertations on Laestadius are mainly rooted in theology and church history, the doctoral theses on the Laestadian movement are rooted in a variety of academic disciplines. A clear tendency shows that most of the earliest dissertations on Laestadianism as a revival movement were rooted in church history and theology.

Figure 2 indicates that there has been a growing interest in research on Laestadius and the Laestadian movement. Looking at twenty year intervals since the first doctoral thesis in 1937, one gets an idea of when the theses have been produced. The most prominent tendency is that fourteen out of twenty-three theses on the Laestadian movement were written after the turn of the millennium. If one looks into the details of these theses, ten 
Figure 2. Theses on Laestadius and the Laestadian movement produced in different periods

\begin{tabular}{l|c|c|} 
Time periods & Laestadius & The Laestadian movement \\
\hline $1937-57$ & 2 & 2 \\
$1958-77$ & 0 & 2 \\
$1979-99$ & 4 & 5 \\
$2000-18$ & 2 & 14 \\
Total & 8 & 23
\end{tabular}

Conservative Laestadianism in other parts of Finland, reached national headlines as well as in Norway and Sweden (see WolfKnuts 2016). Awareness of the Laestadian movement through its public presence might have led to increased interest in the movement, were written in Finland and four in Norway. It is difficult to explain why there has been a peak in the contribution of theses on the Laestadian movement in the last twenty years. Part of an explanation might point to the fact that in the year 2000 there were a range of different seminars on the bicentennial anniversary of Laestadius's birth. These seminars generated news coverage and several publications about Laestadius and the Laestadian movement (cf. Jonsell et al. 2000; Luleå stift 2001; Nesset and Norderval 2000; Nordberg et al. 2000). That might have contributed to the focussing of more attention on Laestadius and the Laestadian movement. Still, there have been only two dissertations on Laestadius himself (Elgvin 2010; Joensuu 2016) since the turn of the millennium.

Another, and more complex, explanation might lie in the increased awareness of the Laestadian movement in different public and popular media, especially in Finland. As Sandra Wallenius-Korkalo (2018) points out in her thesis, the Laestadian movement has been presented in various forms of popular culture (such as literature, movies and theatre) several times since the turn of the millennium. In addition, Conservative Laestadianism in Finland has gained abundant coverage in the public media concerning their reluctance to use contraceptives (see also Ruoho and Ilola 2014). In 200910 news coverage concerning child abuse in the LFF in Ostrobothnia and in and, additionally, made it easier to get funding for PhD projects focussing on the Laestadian movement. In order to get a more solid explanation of the peak in theses on the Laestadian movement after the turn of the millennium, one must map and analyse the motivation behind each thesis.

\section{Theses on Laestadius}

Laestadius is known for his interests and work in many disciplines. In his work as a priest, he started to write down his sermons, especially after the Laestadian revival broke loose. These he sent out with his missionaries. He also wrote an extensive book on (religious) philosophy entitled Dårhushjonet (The Lunatic, Laestadius 1844-57/2015). In addition, he wrote several minor and major works of botany (cf. Laestadius 1839/1993), made meteorological and climate observations (Nissen 1945), wrote about Sami mythology (Laestadius c.1840-5/1997, 2003), and contributed to the development of the Lule Sami language (Rydving 200ob), to mention only some of his works.

The doctoral theses on Laestadius primarily cover his work as a priest and as the 'founder' of the Laestadian movement that is covered.

Seven out of eight theses on Laestadius cover his sermons, theological development and founding of the Laestadian movement (Dahlbäck 1950; Elgvin 2010; H. Juntunen 1982; Kujanpää 1997; Nilsson 
Figure 3. Theses on Laestadius after his work and scientific interests

\begin{tabular}{l|c|c|c|c|c|}
$\begin{array}{c}\text { Sermons, } \\
\text { theological } \\
\text { development }\end{array}$ & $\begin{array}{c}\text { Philosophy } \\
\text { of religion }\end{array}$ & $\begin{array}{c}\text { Natural sciences } \\
\text { (botany, } \\
\text { meteorology }\end{array}$ & $\begin{array}{c}\text { Mythology, } \\
\text { folklore }\end{array}$ & Language \\
\hline Finland & 4 & 1 & 0 & 0 & 0 \\
Norway & 0 & 0 & 0 & 0 & 0 \\
\hline Sweden & 3 & 0 & 0 & 0 & 0 \\
\hline Others & 0 & 0 & 0 & 0 & 0 \\
\hline Total & 7 & 1 & 0 & 0 & 0
\end{tabular}

1988; Outakoski 1991; Zidbäck 1937). Apart from Nilla Outakoski's (1991) thesis in history, the theses are written in church history and theology. Kosti Joensuu's (2016) thesis is the only one on Laestadius's work in philosophy. However, this could also be included in the first category as it also relates to Laestadius's theological development.

The theses in theology go into specific aspects of Laestadius's theology. In the 1980 s and 1990s, four dissertations were done, and offered new perspectives and insights into Laestadius's theology and his view (or idea) of the church. Hannu Juntunen (1982) questioned the established idea that Laestadius's view of the church was based in pietism. Laestadius's concept of God - the heavenly parent - is analysed in Kristina Nilsson's (1988) thesis. Nilsson's work is the first research work that takes a gender perspective. In particular, she shows how Laestadius often uses a female symbolism, and in particular the motherly aspects of God. Outakoski (1991) examines whether there are traces of Sami pre-Christian religion in Laestadius's preaching. Outakoski concludes that Laestadius affirms a belief in mythological creatures de underjordiske (the ones living beneath the ground) in his preaching. Other aspects of Sami pre-Christian religion cannot be demonstrated, according to Outakoski. This thesis relates to questions concerning
Sami mythology and Laestadius's work in this area. However, Outakoski uses Laestadius's sermons in his analysis, and thus does not focus on Laestadius's academic work on Sami mythology.

Lassi Kujanpää (1997) does a rhetorical analysis of fourteen Advent sermons. Kujanpää shows how Laestadius's sermons correspond with classical principles of rhetoric. He argues that Laestadius's sermons correspond with a homiletic textbook by the Swedish theologian Samuel Ödman from the early 1800 s. There are, according to Kujanpää, no explicit references to Ödman in Laestadius's work. LillyAnne Østveit Elgvin's (2010) thesis on the spirituality of Lars Levi Laestadius analyses a selection of all of the 466 sermons by Laestadius which have been preserved.

Compared with the theses in theology, Joensuu's (2016) thesis deals with Laestadius as a philosopher, and relates his thinking to philosophical traditions rather than theological traditions. Joensuu places Laestadius in a philosophical tradition influenced by contemporary classical medical vitalism in the Nordic countries. At the same time, Laestadius stands out by creating a system for religiosity and the religious man as well. Part of Laestadius's philosophical work Dårhushjonet is also characterized by a strong criticism of the rationality of the Enlightenment; nevertheless, it also carries ideas from the 
Enlightenment and romanticism. In Dårhushjonet, Laestadius develops a rational and systematic argument for religiousness and explains pietistic spirituality through scientific and philosophical concepts. He creates a holistic system that sees the physical, moral and spiritual as parts of the whole human being.

Joensuu's thesis is the first major work on Laestadius as a philosopher. Earlier work on the philosophical basis of Laestadius's theology has not been as extensive as Joensuu's thesis. ${ }^{8}$ Joensuu offers a modern philosophical analysis of Laestadius's philosophical work, demonstrating that there are certain philosophical qualities in Laestadius's works. Still, we can say that the philosophical work of Laestadius, until Joensuu's thesis, has been subject to little attention in the research on Laestadius.

The doctoral theses have primarily focused on Laestadius's work in theology and as a priest. They have all been written in Finland and Sweden. ${ }^{9}$ Apart from the smaller contributions mentioned here, there is no major work on Laestadius written by Norwegian researchers submitted as a doctoral dissertation, or equivalent, and published in Norway. In the Swedish and Finnish works, it is mainly Laestadius's theology and preaching that have received attention. This is partly because the revival movement that arose in the wake of his ministry as a priest is the one that has

8 There are minor articles that discuss ideas in Laestadius's work The Lunatic (cf. Bäcksbacka 1939, Steen 1962; Hallencreutz 2000; Norderval 2000; Kristiansen 2004).

9 One of the Swedish theses is written by a Norwegian scholar (Elgvin 2010). influenced the culture and society of northern Scandinavia to the greatest extent. Still, it is rather surprising that there are no doctoral theses on Laestadius's original works in the natural sciences (especially botany), nor his metrological observations, or his observation concerning nature and climate (cf. Laestadius [1824] 1981). The same applies to his work on Sami mythology. Nevertheless, Laestadius's work Fragmenter $i$ lappska mythologin (Laestadius 1997, 2003) is extensively commented on and used in research (cf. Rydving 1995, 2010; Kristiansen 2003) and in doctoral theses on Sami religion (cf. Christoffersson 2010: $76-9) .10$

\section{Theses on the Laestadian movement}

Of the twenty-three theses on the Laestadian movement, fifteen are related to a Finnish university, five Norwegian, and one was written in Sweden (Brännström 1962), the Netherlands (Zorgdrager 1989/1997) and the United States (W. R. Juntunen 1988).

Of the twenty-three theses on the Laestadian movement, there are only five that deal with the early period before the movement was divided into different groups. Some of these theses deal with issues that developed both prior to and

10 See also Håkan Rydving's bibliography on Laestadius's work (Rydving 2000a: 13-23). 
Figure 5. Theses organised after the country in which they are produced and the context the theses deal with

\begin{tabular}{l|c|c|c|c|c|} 
& $\begin{array}{c}\text { Finnish } \\
\text { context }\end{array}$ & $\begin{array}{c}\text { Norwegian } \\
\text { context }\end{array}$ & $\begin{array}{c}\text { Swedish context } \\
\text { Finland }\end{array}$ & $\begin{array}{c}\text { North Ameri- } \\
\text { can context }\end{array}$ & $\begin{array}{c}\text { Other } \\
\text { contexts }\end{array}$ \\
\hline Norway & 0 & 0 & 3 & 1 & 1 (Karelia) \\
\hline Sweden & 0 & 5 & 0 & 0 & 0 \\
\hline Others & 0 & 1 & 1 & 0 & 0 \\
\hline Total & 10 & 6 & 0 & 1 & 0 \\
\hline
\end{tabular}

after the schism of 1901 (cf. Vuollo 1999; Kinnunen 2004; Tapaninen 2007; Larsen 2012; Palola 2015), and thus could have been placed in both categories in Figure 4 .

None of the Norwegian theses has a main focus on the period before 1900. However, both Dagmar Sivertsen (1955) and Rolf Inge Larsen (2012) partly cover developments before 1900. Their focus is the early phase of the Laestadian movement in Norway in order to map and explain later developments.

There is a clear pattern that theses cover the Laestadian movement in the same national context in which they are written. Theses written in Finland primarily cover the Finnish context, the Norwegian theses cover Norway, and so on. The themes of the theses rarely go into issues concerning the Laestadian movement as a transnational revival movement. The exceptions are the Finnish theses by Mauri Kinnunen (2004) and Tuomas Palola (2015), and to some extent Pekka Tapaninen (2007). Kinnunen (2004) writes about how the Laestadian movement was established in Karelia in the period 1870 to 1939. Palola's (2015) thesis discusses the questions of identity and language in the Laestadian movement in the United States during the period from 1884 to 1929. These two theses are the only ones written in a Nordic country that cover the Laestadian movement outside the Nordic context. Tapaninen's (2007) thesis on the
Laestadian preacher Oskari Heikki Jussila (1888-1955), does, however, offer insights on the Laestadian context in the United States. The thesis by Wayne Roger Juntunen (1988), covers Laestadianism in the United States. Theses by Martti E. Miettinen (1942), Pekka Raittila (1976), Olaus Brännström (1962) and Gerd Snellman (2011) all cover the Laestadian movement in a SwedishFinnish context.

As stated above, the theses do to a very small extent reflect that the Laestadian movement is a transnational revival movement; albeit almost all of the theses in their introductions describe the Laestadian movement as an international one. The idea or the perspective on the Laestadian movement as an international one is thus present, but not a main focus.

Eight Finnish theses can be placed in the field of church history (Miettinen 1942; Raittila 1976; Talonen 1988; Snellman 2011; Kejonen 2014; Palola 2015; Nurminen 2016; Rantala 2018), along with one from Norway (Sivertsen 1955), Sweden (Brännström 1962) and the United States (W. R. Juntunen 1988) respectively. The thesis in church sociology (Hintsala 2017) was delivered at a theological faculty (Faculty of Theology at the University of Helsinki). Church history was the only academic discipline that produced doctoral theses on the Laestadian movement until Zorgdrager's ([1989]1997) thesis of 
Figure 6 . Theses on the Laestadian movement after country and academic discipline

\begin{tabular}{l|c|c|c|c|c|c|}
\hline Finland & $\begin{array}{c}\text { Church history / } \\
\text { theology }\end{array}$ & $\begin{array}{c}\text { Church } \\
\text { sociology }\end{array}$ & $\begin{array}{c}\text { Study of } \\
\text { religions }\end{array}$ & History & $\begin{array}{c}\text { Social anthro- } \\
\text { pology }\end{array}$ & $\begin{array}{c}\text { Political } \\
\text { science }\end{array}$ \\
\hline Norway & 1 & 1 & 0 & 4 & 0 & 2 \\
\hline Sweden & 1 & 0 & 2 & 1 & 1 & 0 \\
Others & 1 (US) & 0 & 0 & 0 & 0 & 0 \\
\hline Total & 11 & 1 & 2 & 5 & 1 & 0 \\
\end{tabular}

1989. In the Nordic countries, Vuollo's (1999) thesis in history seems to be the first that was not delivered at a theological faculty. After Vuollo's (1999) thesis, four more theses have been written as theses in history (Kinnunen 2004; Tapaninen 2007; Larsen 2012; Rantala 2018).

Nellejet Zorgdrager's (1989/1997) thesis is, together with Marit Myrvoll's (2011), the only two offered in social anthropology. Zorgdrager delivered her thesis on the Kautokeino uprising in 1852 at the University of Groningen in 1989. Zorgdrager argues that she wishes to give a broader account of what happened before, during and immediately after the Kautokeino uprising in 1852. A key point in her dissertation is to bring in source material 'in order to be able to portray life in Kautokeino in a larger social context' (Zorgdrager 1997: 28). She gives great importance to Laestadius's preaching and the context of the Laestadian movement in Kautokeino. Zorgdrager's dissertation analyses and discusses a key event in the early history of the Laestadian movement in Norway. The Laestadian movement is related to its social context, but also to the old Sami religion (shamanism). Although the thesis is limited to a historical context, Zorgdrager presents larger hypotheses or generalisations about the movement (cf. Andreassen 2017: 81).
Myrvoll's theoretical perspectives, based on Peter Berger's, as well as Thomas Luckmann and Clifford Geertz's works, illustrate the social anthropological perspective. Her fieldwork was conducted in a local community in Northern Norway which is dominated by the Laestadian Firstborn group. She uses the theoretical perspectives in a discussion of how reality is established and maintained through religion. Myrvoll delineates and specifies 'religious and religious reality' to 'various aspects of faith. The focus on continuity and change in people's understanding is confined to religiosity and beliefs, and the consequences it has for modern life.

In his thesis on the Lyngen group, Torjer A. Olsen (2008) applies theoretical perspectives from study of religions scholars such as Bruce Lincoln and Russell T. McCutcheon, as well as from gender studies scholars such as Joan W. Scott. Torgeir Nordvik (2015) labels his thesis on the Firstborn and Lyngen groups' relation to the Church of Norway after 2000, as a church-historical project, using theories from Niklas Luhmann's work on the autopoietische Systeme. It is worth noticing that Olsen's and Nordvik's ${ }^{11}$ are the only

11 Nordvik places his thesis (2015) within church history, although delivered at the Department for History and Study of 
two theses in the study of religions, both delivered at UiT The Arctic University of Norway in Tromsø. The study of religions was established there in 1995, and one of the intentions was to stimulate research on religious life in northern Norway and the Arctic region. In general, there has been rather little interest in research on the Laestadian movement by scholars in the study of religions.

Also worth noticing is that there are two Finnish theses in the field of political science. Tapio Nykänen (2012) discusses the Laestadian movement's theology (represented by Conservative Laestadianism) and its political implications. Nykänen's point of departure is that the Laestadian movement - in addition to being a religious movement - also represents a political one. He argues that Laestadian theology has social and thus political implications. Nykänen particularly emphasizes that Laestadian theology is largely interpreted with references to 'the other(s)', 'the world' and 'non-believers'. Among these are other Christian groups. This makes Conservative Laestadianism an exclusive movement, affecting its surroundings accordingly. Sandra WalleniusKorkalo (2018: 7) draws on several academic disciplines: feminist political studies, religious studies and cultural studies. Wallenius-Korkalo's dissertation analyses and discusses how Laestadianism appears in popular cultural expressions such as fiction (literature), film and theatre. In particular, she looks at 'bodily expressed Laestadianism' and the power structures that lie in 'religious corporeality'. She asks 'how Laestadianism is embodied and how its representations participate

Religions at University of Tromsø. This has to do with the department's divided profile, offering both theology (and church) history and study of religions. in making sense of the political potential of the Laestadian body'. She suggests that 'the power at issue constructs, maintains and divides the religious collective and is focused on, materializes in, and originates from the body' (Wallenius-Korkalo 2018: 7). Wallenius-Korkalo argues that the popular publications reveal the presence of Laestadianism in the social debate and cultural consciousness. According to Wallenius-Korkalo, the representations of Laestadianism in popular culture revolve around a triad of care, longing and social control. Wallenius-Korkalo argues that these three elements appear to be highly politicized when linked to issues of belonging or non-belonging to the Laestadian tradition.

\section{Discussion}

Main tendencies in the theses on Laestadius

The theses on Laestadius are still rather few, and theological discussions are the most prominent tendency in the theses on Laestadius. Kosti Joensuu's (2016) thesis stands out as an original contribution in the research on Laestadius. Joensuu's focus is on Laestadius's religious-philosophical/ religious-psychological work Dårhushjonet, and the aim is to analyse and interpret Laestadius's philosophical and psychological perspectives and ideas. Thus, Joensuu's thesis discusses aspects of Laestadius that have been looked at to a very little extent in earlier research. Joensuu discuss Laestadius's ideas in relation to philosophical ideas and trends, which makes this an innovative and valuable contribution to the research on Laestadius.

In biographical sketches of Laestadius - encyclopaedias, textbooks, or in introductions to doctoral theses on Laestadius or the Laestadian movement - his work in botany, linguistics and folklore/mythology are usually mentioned. The absence of 
doctoral theses on Laestadius's works in these areas is therefore striking. Laestadius's work as a mythologist is richly commented upon (cf. Pulkkinen 2000; Pentikäinen 2000) and in research on Sami religion, Laestadius's work on Sami mythology is broadly referred to and discussed (Rydving 1995; Christoffersson 2010). It is, thus, something that is rather richly covered in research even if there are no doctoral theses that has Laestadius as a mythologist as its main focus.

The same might apply to Laestadius's work in botany, or other natural sciences. There are no doctoral theses covering this. However, Olle Franzén's book Naturalhistorikeren Lars Levi Laestadius (1973), covers several aspects of this, and in many respects is equivalent to a doctoral thesis. After Franzén's book, several minor articles have been published about Laestadius's work in botany (cf. Jonsell 2000; Elven 2000; Nordal and Jonsell 2000; Sortland 2016).

Juha Pentikäinen (2000: 78) suggests that Laestadius's contributions in the fields of botany, ethnography and mythology are something that have been overshadowed by the revival that occurred on the basis of speeches he made in his work as a priest. That is indeed a part of the explanation of why most of the doctoral theses on Laestadius concern his work as a priest. Still, the doctoral theses (or research in general) on Laestadius's works in the natural sciences, ethnography and mythology is something that should be given more attention in research. One of the challenges is to recruit researchers within the natural sciences, ethnography and mythology who might be interested in Laestadius's contribution within these fields. In church history, theology and the study of religions, it is a given that his work has been of major influence.
Main tendencies in theses on the Laestadian movement

The numbers in the figures above have clearly illustrated that most of the doctoral theses on the Laestadian movement are produced in Finland. The most surprising finding in this review is that there is only one doctoral thesis on the Laestadian movement produced in Sweden. However, this does not indicate that there has not been research on the Laestadian movement in Sweden. As illustrated above - research has been published in other academic genres. Beyond this, it is difficult to explain why there is only one Swedish doctoral thesis on the Laestadian movement - and that delivered almost sixty years ago. Still, it indicates that it has been difficult to recruit young scholars to do a doctoral project on the Laestadian movement. It also might indicate that it has been difficult to finance a doctoral project because the Laestadian movement has not been prioritized at the universities. However, it is worth noting because the Laestadian movement was first established in Sweden and has been a dominant aspect of the religious context in northern Sweden. The fact that it has been a phenomenon in northern Sweden might also - paradoxically - help explain why there is only one thesis: the Laestadian movement has been considered as peripheral to mainstream Swedish church history. ${ }^{12}$ The situation thus has similarities to that in Norway. In both countries, the Laestadian movement is rarely discussed in

12 A part of the picture to illustrate that the Laestadian movement might be referred to as peripheral in Swedish church history, is the fact that the translations and publishing of Laestadius's speeches have primarily been done by Laestadians themselves (Andreassen 2019). Laestadius's speeches have had no place in the Swedish church. 
national church histories (Olsen 2010). In comparison, the Laestadian movement was also established in larger cities in Finland, as well as in the south, making it a more mainstream phenomenon compared to the neighbouring countries (Pentikäinen 1985: 156).

In the theses on the Laestadian movement, the focus is on how the movement spread (Miettinen 1942; Raittila 1976; Lohi 1997), came to a specific area, and was established there (Sivertsen 1955; Vuollo 1999; Zorgdrager 1997; Kinnunen 2004; Palola 2015). In later theses, the research design seems to be more critical-analytical and have resulted in theses that are more thematically focused on special issues, which are discussed in depth, especially concerning sexuality and gender (Olsen 2008; Snellman 2011; Kejonen 2014; Hintsala 2017; Rantala 2018; WalleniusKorkalo 2018), as I will return to below. Two theses focus on the Laestadian movement and politics (Nykänen 2012; Talonen 1988).

Surprisingly few theses have had a biographical focus. Tapaninen's (2007) is the only thesis that follows a Laestadian preacher. This gives an interesting approach to research on the Laestadian movement that might be developed. Especially in order to say more about the lay preacher, which has been 'the main rule' in the Laestadian movement.

\section{The Laestadian groups covered in the theses}

It is a clear tendency that the Norwegian theses cover the Laestadian movement in Norway, while the Finnish focus on Finland, the Swedish on Sweden, and the North Americans on the movement in the United States. The theses cover the national context in which they are produced. Another question is whether there are specific groups that are represented in the doc- toral theses and others not. The question is of relevance in reference to the fact there are several different Laestadian groups. If one takes a closer look at the theses that cover the movement after 1901, one can map some tendencies. Especially, theses produced after the turn of the millennium.

Among the Finnish, Snellman (2011) is the only one to write about LFF, while the other recent Finnish theses have focused on Conservative Laestadianism (Hintsala 2017; Kejonen 2014; Nurminen 2016; Nykänen 2012; Wallenius-Korkalo 2018). In the Norwegian dissertations, the focus is on the Lyngen group (Larsen 2012; Nordvik 2015; Olsen 2008), and the Firstborn group (Myrvoll 2011; Nordvik 2015). Only Nordvik and Larsen discuss two or more Laestadian groups in the same dissertation. Larsen (2012) refers to several different Laestadian groups but does not go into detail about them. Nordvik's (2015) thesis stands out by discussing and comparing two Laestadian groups' relationship to the Church of Norway.

Myrvoll's (2011) is the only doctoral thesis that has a primary focus on the Firstborn Laestadians. None of the Finnish theses focus on them. ${ }^{13}$ If one looks to Sweden, there is no research covering the Firstborn Laestadians, be it doctoral theses or other research. In Norway, there is very little written about the Firstborn group, ${ }^{14}$ and hardly anything written about the Alta

13 There are several other examples of Finnish research on the Firstborn group (e.g. Ihonen 1987; Talonen 1993; Hokka 2006). Still, the research on SRK / Old Laestadian group / Conservative Laestadians is dominant.

14 In addition to Nordvik's articles in his thesis, some minor articles have been written by Bengt-Ove Andreassen (2011, 2012), Roald Kristiansen (2016), Rolf Inge Larsen (1997) and May Lunde (1986, 2001). 
group (except Leganger-Krogstad 1995) with the LFF as a sister group in Finland and Sweden, and the research literature on the New Awakening is non-existent. One might also add minor groups after different schisms such as the Laestadianska Missionsförbundet (Laestadian Missionary Society) in Sweden, Elämän Sana (Word of Life) in Finland, or the Levi group in Finland and Sweden.

Taking into account that the Laestadian movement is a highly international one (cf. Talonen 2001), there are surprisingly few theses that have focused on the movement outside the Nordic countries. Theses by Kinnunen (2004) and Palola (2015) are the only two that have a main focus on establishment (Kinnunen in Karelia) or development (Palola in the US) outside the Nordic countries. The lack of theses on the international dimension of the Laestadian movement is also something that applies for the research in general.

Research on different Laestadian groups, and Laestadian groups in different (national) contexts, not only maps the differences in the Laestadian movement, it also illustrates that 'Laestadianism' is a generic term and must be used as such. It will also illustrate that the Laestadian movement is a typical religious movement, in which every sub-group argues that they are maintaining the authentic Laestadian teaching. Thus, focus on different Laestadian groups will illustrate that religion is contextual and dynamic, and dependent on human interpretation and reception.

\section{New theoretical approaches, new perspectives} The dissertations after the turn of the millennium are characterized by use of new theoretical concepts in the social sciences and theology, especially discourse analysis related to sexuality/gender and power. This is not something special for theses on the
Laestadian movement. Rather, it follows general patterns in doctoral theses within humanities and social sciences.

Discourse analysis is a generic term covering a heterogeneous number of theoretical approaches and analytical constructs (Muncie 2006: 74; Hjelm 2011). It is a qualitative research design, in which the analysis of different data materials as text (such as documents, newspapers, communication or social media), is carried out in order to detect relations between language, communication, knowledge and power in social practices. One might say that it focuses upon the meaning and structure (whether overt or hidden) of acts of communication in context. A discourse approach can thus be described as critical. It presupposes that there is a meaning beyond the immediate message of a text or communication.

The theses applying a discourse-analytical approach, in some shape or another, introduce critical perspectives in the research on the Laestadian movement to an extent that is rather new. Whereas most of the theses written before the turn of the millennium (and some after, such as Kinnunen 2004; Myrvoll 2011; Snellman 2011) have a more descriptive and hermeneutical approach, the later theses have a more critical approach (such as Kejonen 2014; Larsen 2012; Nordvik 2015; Nykänen 2012; Olsen 2008; Rantala 2018; WalleniusKorkalo 2018). These theses also illustrate that the Laestadian movement is highly relevant as a context for discussing the body, sexuality (homosexuality, contraceptives) and gender, where Laestadianism represents a pre-modern (religious, Christian) view in conflict with a modern (secular, non-religious, or liberal Christian/theological) view. These theses thus take a step further from that of describing a historical development, or how the Laestadian movement was established in a local community, 
to a more thematic and critical discussion of aspects related to power structures within the movement. Hence, one might say that these perspectives treat the Laestadian movement as, in Russell T. McCutcheon's (2001) words, something ordinary - and as a typically religious tradition (religion), and not as something special, original or exclusive compared to other religious traditions, which often has been the case in more theologically based research.

\section{Conclusion}

Doctoral theses on Laestadius are still few, and mainly focus on his work as a priest. Theses on the Laestadian movement have gained more attention, and have increased rapidly in numbers since the turn of the millennium. Finland stands out, by far, as the country in which the most doctoral theses on Laestadius and the Laestadian movement have been produced.

The theses on the Laestadian movement are influenced by theoretical trends in the social sciences. This has resulted in the production of theses on the Laestadian movement that are more thematically and critically oriented. This review has also displayed that there is a tendency that the research in doctoral theses is limited to a national context even though several groups in the Laestadian movement are transnational. Finnish researchers have focused on groups in Finland (especially Conservative Laestadianism) and Norwegian researchers have focused on Laestadian groups in Norway (especially the Lyngen group). This has meant that several Laestadian groups are more or less absent in the research.
Bengt-Ove Andreassen, $\mathrm{PhD}$, is a full professor in the field of the study of religions at the Department of Education, UiT The Arctic University of Norway. His main areas of research are the didactics of religions (RE), religion

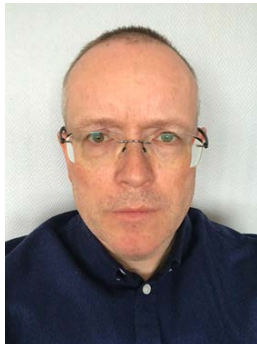
in public education and the Laestadian revival movement. Among his publications are Textbook Gods (ed. together with James R. Lewis, Equinox 2014), 'A review of theories on the Laestadian rørelse: on the academic construction of something extraordinary and exotic', in Acta Borealia, 34(1), 2017, pp. 70-89, and '“Knowledge about religions" and analytical skills in religious education: reflections from a Norwegian context', in Center for Educational Policy Studies Journal - CEPS Journal, 9(4), 2019, pp. 73-90.

\section{Bibliography}

\section{Doctoral theses on Lars Levi Laestadius}

Dahlbäck, Gustaf, 1950. Den gamla och den nya människan i Lars Levi Lostadius' teologi (Lund, Skånska centraltryckeriet)

Elgvin, Lilly-Anne Østveit, 2010. Lars Levi Loestadius' spiritualitet (Umeå University)

Joensuu, Kosti, 2016. The Physical, Moral and Spiritual: A Study on Vitalist Psychology and the Philosophy of Religion of Lars Levi Laestadius (Rovaniemi, University of Lapland)

Juntunen, Hannu, 1982. Lars Levi Loestadiuksen käsitys kirkosta, Suomalaisen Teologisen Kirjallisuusseuran julkaisuja, 132 (Helsinki, Suomalainen Teologinen Kirjallisuusseura)

Kujanpää, Lassi, 1997. Kristillinen saarna. Lars Levi Laestadiuksen funktionaalis-historiallinen analyysi (University of Oulu)

Nilsson, Kristina, 1988. Den himmelska Föräldern. Ett studium av kvinnans betydelse $i$ och för Lars Levi Laestadius' teologi och förkunnelse (Uppsala, Almqvist \& Wiksell)

Outakoski, Nilla, 1991. Lars Levi Loestadiuksen saarnojen maahiskuva verrattuna Kaaresuvannon nomadien maahiskäsityksiin, Scripta Historica, 17 (Oulu, Oulun historiaseura)

Zidbäck, Aulis, 1937. Lars Levi Laestadiuksen kristillisyyden-näkemys. Erityisesti silmällä pitäen Kristuksen seuraamisen ihannetta (Turku) 
Doctoral theses on the Laestadian movement

Brännström, Olaus, 1962. Den laestadianska själavårdstraditionen $i$ Sverige under 180otalet, Bibliotheca Theologiae Practicae (Uppsala, CWK Gleerups förlag)

Hintsala, Meri-Anna, 2017. Taivasta varten luotu. Usko ja ruumis vanhoillislestadiolaisuutta koskevissa verkkokeskusteluissa (University of Helsinki)

Juntunen, Wayne Roger, 1988. 'Where is the Apostolic Lutheran Church Going?', a dissertation presented to the Faculty of Faith Evangelical Lutheran Seminary (Tacoma, Washington)

Kejonen, Eetu, 2014. Sexualitet i en brytningstid. En etisk analys av två finlänska väckelserörelsers syn på samhälle, kyrka och homosexualitet åren 1970-2011 (Åbo Akademis förlag)

Kinnunen, Mauri, 2004. Herätysliike kahden kulttuurin rajalla. Lestadiolaisuus Karjalassa 1870-1939, Jyväskylä Studies in Humanities, 19 (University of Jyväskylä)

Larsen, Rolf Inge, 2012. Religion og fiendebilder. Loestadianismen, statskirken og kvenene 1870-1940 (University of Tromsø)

Lohi, Seppo, 1997. Pohjolan kristillisyys. Lestadiolaisuuden leviäminen Suomessa 18701899 (Oulu, Suomen Rauhanyhdistyksen Keskusyhdistys)

Miettinen, Martti E., 1942. Lestadiolainen herätysliike I. Perustajan aika (Helsinki, Otava)

Myrvoll, Marit, 2011. "Bare gudsordet duger». Om kontinuitet og brudd i samisk virkelighetsforståelse (University of Tromsø)

Nordvik, Torgeir, 2015. Lestadianerne og kirken. De førstefødtes og Lyngen-retningens forhold til Den norske kirke ved inngangen til 200o-tallet (University of Tromsø)

Nurminen, Hanna, 2016. Jumala vai minä? Kaksi käsitystä vanhurskauttamisesta 1970luvun vanhoillislestadiolaisuudessa (University of Helsinki, Faculty of Theology)

Nykänen, Tapio, 2012. Kahden valtakunnan kansalaiset. Vanhoillislestadiolaisuuden poliittinen teologia, Acta Universitatis Lapponiensis, 237 (Rovaniemi, University of Lapland)

Olsen, Torjer A., 2008. Kall, skaperordning og makt. En analyse av kjønn i lyngenloestadianismen (University of Tromsø)

Palola, Tuomas, 2015. Amerikkalainen vai pohjoismainen? Amerikan apostolis-luterilaisuus 1884-1929 (Oulu, Suomen Rauhanyhdistysten Keskusyhdistys ry).

Raittila, Pekka, 1976. Lestadiolaisuus 1860luvulla. Leviäminen ja yhteisönmuodostus (Helsinki, Akateeminen kustannusliike)

Rantala, Teija, 2018. Beyond Sisters and Mothers: Women's Aspirations in Conservative Laestadian Movement (University of Helsinki)

Sivertsen, Dagmar, 1955. Loestadianismen $i$ Norge (Oslo, Forlaget Land og kirke)

Snellman, Gerd, 2011. Sions döttrar. De laestadianska kvinnorna som traditionsförmedlare i norra svenska Österbotten åren 1927-2009 (Åbo Akademis förlag)

Talonen, Jouko, 1988. Pohjois-Suomen lestadiolaisuuden polittis-yhteiskunnallinen profili 1905-1929, Finska kirkkohistoriallisen seuran toimituksia, 144 (Helsinki, Suomen kirkkohistoriallinen seura)

Tapaninen, Pekka, 2007. Oskari Heikki Jussila (1888-1955). Lestadiolaispappi, toimen ja näkyjen mies, Studia Historica Septentrionalia, 52 (Rovaniemi, Pohjois-Suomen historiallinen yhdistys)

Vuollo, Martti, 1999. Lestadiolaisuus Helsingissä vuoteen 1963, Studia historica septentrionalia, 37 (Jyväskylä, Gummerus)

Wallenius-Korkalo, Sandra, 2018. Esitetty lestadiolaisuus. Uskonto, ruumiillisuus ja valta populaarikulttuurissa, Acta Universitatis Lapponiensis, 373 (Rovaniemi, University of Lapland)

Zorgdrager, Nellejet, (1989) 1997. De rettferdiges strid. Kautokeino 1852 (Oslo, Vett og viten)

\section{References}

Amirell, S. E., 2006. 'Den internationella historiens uppgång och fall. Trender inom svensk internationell historieforskning 1950-2005', in Historisk Tidskrift, 126(2), pp. 257-78

Andreassen, Bengt-Ove, 2011. 'History as religious self-mediation. The case of the Firstborn Laestadians', in Acta Borealia, 28(1), pp. $1-18$

-_-2012. 'Førstefødtlæstadianernes selvrepresentasjon. En analyse av to brosjyrer', in Nordlit, 30, pp. 35-50

- - 2017. 'A review of theories on the Laestadian rørelse: on the academic construction of something extraordinary and exotic, 
in Acta Borealia, 34(1), pp. 70-89, doi: $<$ https://doi.org/10.1080/08003831.2017.1 323482>

—_-2019. 'Taler i trykk. Bokhistoriske perspektiver på utgivelser av Læstadius' taler', in Din. Tidsskrift for religion og kultur, 1, pp. 7-33

Auranen, Ari, 2008. Lestadiolais-uuspietistinen konservatiiviteologi. Uuras Saarnivaaran elämä ja toiminta vuoteen 1966 (University of Oulu)

Bäcksbacka, Erik, 1939. 'Lars Levi Laestadius' religionsfilosofiska arbete "Dårhushjonet»: dess tillblivelse och syfte, in Suomen kirkkohistoriallisen seuran vuosikirja 27, pp. 1-80

Bjørklund, Ivar, 1985. Fjordfolket $i$ Kvæenangen. Fra samisk samfunn til norsk utkant 15501980 (Oslo, Universitetsforlaget)

Boreman, Per, 1953. Loestadianismen. Fennoskandiens märkligaste väckelse och dess förhållande till kyrkan (Stockholm, Svenska kyrkans diakonistyrelsens bokförlag)

Brännström, Olaus, 1990. Lannavaara-missionen och loestadianismen (Stockholm, Almqvist \& Wiksell International)

Christoffersson, Rolf, 2010. Med tre röster och tusende bilder. Om den samiska trumman (Uppsala Unversity)

Elenius, Lars, 2001. Både finsk och svensk. Modernisering, nationalism och språkförändring i Tornedalen 1850-1939 (Umeå University)

Elven, Reidar, 2000. 'Det konfliktfylte artsbegrepet hos Læstadius og hans samtidige, in Lars Levi Loestadius. Botaniker - lingvist - etnograf - teolog, eds. Bengt Jonsell, Inger Nordal and Håkan Rydving (Oslo, Novus), pp. 51-6

Franzén, Olle, 1973. Naturalhistorikern Lars Levi Laestadius, Tornedalica, 15 (Luleå, Tornedalica)

Hallencreutz, Carl Fredrik, 200o. 'Pastoralteologi i samisk miljö: ett perspektiv på Dårhushjonet', in Lars Levi Loestadius. Botaniker - lingvist - etnograf - teolog, eds. Bengt Jonsell, Inger Nordal and Håkan Rydving (Oslo, Novus), pp. 117-28

Heith, Anne, 2018. Laestadius and Laestadianism in the Contested Field of Cultural Heritage: A Study of Contemporary Sámi and Tornedalian Texts (Umeå University)

Hjelm, Titus, 2011. 'Discourse analysis', in The Routledge Handbook of Research Methods in the Study of Religion, eds. Michael Stausberg and Steven Engler (London, Routledge), pp. 134-50

Hokka, Leena, 2006. 'Suomen esikoislestadiolaisten ja Ruotsin äitiseurakunnan suhteen rakentuminen Rauhan Side -lehdessä', in Växelverkan och identitet. Kyrka och religion i Finland och Sverige 1809-1999, eds. Ingvar Dahlbacka and A. Swanström (Åbo, Kyrkohistoriska arkivet vid Åbo Akademi), pp. 173-204

Ihonen, Markku, 1987. Lähetyskäskyn tulkinta ja toteuttaminen esikoislestadiolaisuudessa. Eräitä taustoja (Joensuu)

Jonsell, Bengt, 200o. 'Lars Levi Læstadius i sin botaniska samtid', in Lars Levi Loestadius. Botaniker - lingvist - etnograf - teolog, eds. Bengt Jonsell, Inger Nordal and Håkan Rydving (Oslo, Novus), pp. 33-50

Jonsell, Bengt, Inger Nordal, and Håkan Rydving (eds.), 2000. Lars Levi Loestadius. Botaniker - lingvist - etnograf - teolog (Oslo, Novus)

Kristiansen, Roald E., 2003. 'Gudelæren i L. L. Læstadius' Fragmenter i lappska mythologien', in Lars Levi Læstadius, Fragmenter $i$ lappska mythologien. Gudalära (Tromsø, Angelica), pp. 175-84

- - 2004. 'Religious philosophy for fools: on the philosophical basis for L. L. Læstadius' theology', in The Legitimacy and Autonomy of Religion: Lectures Given at an International Symposium for Philosophy of Religion at the University of Tromsø, Norway August/September 2001, eds. Ketil Bonaunet and Roald E. Kristiansen (University of Tromsø), pp. 65-82

- - 2016. 'Lappmarkens kristendom og de førstefødtes menighet', in Norsk tidssksrift for misjonsvitenskap, 2-3, pp. 37-47

Laestadius, Lars Levi, (1824) 1981. Uppodlingar i Lappmarken, Tornedalica, 33 (Luleå, Tornedalica)

-_-(1839) 1993. Loca parallela plantarum, Tornedalica, 51 (Luleå, Tornedalica)

-_-(1840-5) 1997. Fragmenter i lappska mythologien (Åbo, NIF)

- - (1840-5) 2003. Fragmenter i lappska mythologien. Gudalära (Tromsø, Angelica)

Larsen, Hallvard, 1997. 'Fra periferibevegelse til storsamfunnsinstitusjon. Utviklingslinjer i læstadianismen i Ofoten 1848-1970, 
in Stat, religion, etnisitet, eds. Bjørn-Petter Finstad, Lars Ivar Hansen, Henry Minde and Hallvard Tjelmeland (Tromsø, Senter for samiske studier), pp. 189-213

Leganger-Krogstad, Heid, 1995. Loestadianske oppdragelsesidealer og skolekonflikten i Alta: foreldrenes ønsker for opploering og oppdragelse, HiF-rapport (Alta, Høgskolen i Finnmark)

Lindin, Leif, and Håkan Rydving, 2007. Samisk kyrkohistorisk bibliografi (Umeå University)

Luleå stift, 2001. Laestadius ropar ännu. En serie förelesningar om Lars Levi Laestadius förförda i Pajala under Laestadiusåret 2000 (Luleå stift)

Lunde, May, 1986. 'The Old Apostolic Church of Calumet, Michigan', in Essays on NorwegianAmerican Literature and History, eds. Dorothy Burton Skårdal and Ingeborg R. Kongslien (University of Oslo), pp. 273-83

_-_2001. 'Læstadianismen: hovedtrekk fra historien til Nordkalottens vekkelsesbevegelse i Nord-Norge og i USA', in Dissentere og emigrasjonen (Oslo, Norges frikirkeråd), pp. 93-150

Mäkitalo, Leena, 2016. Rajan ylityksiä. AnnaMaija Raittilan runouden kristillisyydestä (Helsinki, Unigrafia)

McCutcheon, Russell T., 2001. Critics not Caretakers: Redescribing the Public Study of Religion (Albany, State University of New York Press)

Muncie, John, 2006. 'Discourse analysis', in The Sage Dictionary of Social Research Methods, ed. Victor Jupp (London, Sage), pp. 74-6

Nesset, Sigmund, and Øyvind Norderval (eds.), 2000. Vekkelse og vitenskap: Lars Levi Loestadius 200 år (Tromsø, Ravnetrykk)

Nissen, Kristian, 1945. 'Et brev fra Lars Levi Læstadius om vegetasjonens tilbakegang på grunn av klimaforverring', in Blyttia, 3, pp. $38-42$

Nordal, Inger, and Bengt Jonsell, 2000. ' ... besynnerligt nog har Fries förbigått att göra arter af dem... Læstadius' artsbegrep i et upublisert arbeid om skjørbuksurt, Coclearia', in Lars Levi Lostadius. Botaniker - lingvist etnograf - teolog, eds. Bengt Jonsell, Inger Nordal and Håkan Rydving (Oslo, Novus), pp. $57-68$

Nordberg, Henri, Kenneth Mikko, and AnnChristine Haupt (eds.), 2000. Tornedalens årsbok 2000 (Tornio, Tornionlaakson neuvosto)

Norderval, Øyvind, 200o. “"Kirken - en oppfostringsanstalt for buken”: Lars Levi Læstadius' kirke- og prestekritikk', in Vekkelse og vitenskap: Lars Levi Lostadius 200 år, eds. Sigmund Nesset and Øyvind Norderval (Tromsø, Ravnetrykk), pp. 53-73

Olsen, Torjer A., 2010. 'Vår vekkelse og de andres vekkelse. En analyse av faglige framstillinger av haugianisme og læstadianisme', in Speculum Boreale, 13 (University of Tromsø), pp. 138-53

Pentikäinen, Juha, 1985. 'De finländska väckelserörelserna som region-kulturer', in Religiösa väckelserörelser $i$ Norden, ed. Anders Gustavsson (Lund, Centrum för religoinsetnologisk forskning), pp. 154-65

-_-2000. 'Lapparnes indre hushållning... Religionsbegreppet hos Lars Levi Læstadius, banbrytare i religionsetnografi och fältforskning, in Lars Levi Loestadius. Botaniker - lingvist - etnograf - teolog, eds. Bengt Jonsell, Inger Nordal and Håkan Rydving (Oslo, Novus), pp. 77-94

Petticrew, Mark, and Helen Roberts, 2006. Systematic Reviews in the Social Sciences: A Practical Guide (Oxford, Blackwell Publishing)

Pohjanen, Bengt, 1979. Med seende ögon. En studie $i$ Antti Hyrys författarskap (Stockholm University)

Pulkkinen, Risto, 2000. 'Lars Levi Læstadius och den finska mytologiska skolan', in Lars Levi Lostadius. Botaniker - lingvist - etnograf - teolog, eds. Bengt Jonsell, Inger Nordal and Håkan Rydving (Oslo, Novus), pp. 95-105

Raittila, Pekka, 1967. Lestadiolaisuuden matrikkeli ja bibliografia (Helsinki, Suomen kirkkohistoriallinen seura)

Ruoho, Aila, and Vuokko Ilola, 2014. Usko, toivo ja raskaus. Vanhoillislestadiolaista perheelämää (Helsinki, Atena Kustannus Oy)

Rydving, Håkan, 1995. Samisk religionshistoria. Några källkritiska problem (Uppsala University)

- - 2000a. 'Bibliographia laestadiana selecta', in Lars Levi Loestadius. Botaniker - lingvist - etnograf - teolog, eds. Bengt Jonsell, Inger Nordal and Håkan Rydving (Oslo, Novus), pp. 13-32 
200ob. 'Lars Levi Læstadius og det første lulesamiske skriftspråket', in Lars Levi Loestadius. Botaniker - lingvist - etnograf teolog, eds. Bengt Jonsell, Inger Nordal and Håkan Rydving (Oslo, Novus), pp. 69-76

-_-2010. Tracing Sami Traditions (Oslo, Novus)

Ryymin, Teemu S., Astrid Andresen, Jan Heiret, and Leidulf Melve, 2019. 'Hovedtendenser i norsk historievitenskap 1969-2015 belyst gjennom doktorgradsavhandlinger', in Historisk tidsskrift, 98(2), pp. 130-66

Sortland, Andy, 2016. 'Mellom Ararat og Tsjatja - botanikeren Lars Levi Læstadius', in Norsk tidsskrift for misjonsvitenskap, 2-3, pp. 9-15

Steen, Adolf, 1962. 'Lars Levi Læstadius og hans dom over kolleger', in Norsk teologisk tidsskrift, 63, pp. 111-23

Stuckrad, Kocku von, 2014. The Scientification of Religion: An Historical Study of Discursive Change 1800-200o (Berlin, De Gruyter)

Talonen, Jouko, 1993. Esikoislestadiolaisuus ja suomalainen yhteiskunta 1900-1944 (Helsinki, Suomen kirkkohistoriallinen seura)

- - 2001. 'Laestadianismen in an international perspective', in HiF-Rapport 2001:6, Læstadius 200 år (Alta, Høgskolen i Finnmark), pp. 53-9

Thulin, Henning, 1949. Lars Levi Laestadius och hans förkunnelse (Stockholm, Förlaget Filadelfia)

Vuollo, Martti, 2006. Jyrisevä kouluneuvos tunnollinen pedagogi. Martti E. Miettinen kasvattajana ja opettajana (Rovaniemi, University of Lapland)

Wikmark, Gunnar, 1980. Lars Levi Lostadius' väg till nya födelsen (Stockholm, Samlingar och studier till Svenska kyrkans historia)

Wolf-Knuts, Ulrika, 2016. 'Lived forgiveness in a Finland-Swedish Laestadian community', in The Shifting Boundaries of Tolerance: Inclusion, Exclusion, and Religious Communities of Memory, eds. Ingvar Dahlbacka, Kim Groop and Jakob Dahlbacka, Studies on Religion and Memory, 2 (Åbo Akademi), $<$ https://ojs.abo.fi/ojs/index.php/relmem/ article/view/966 $>$ (accessed 2.4.2020) 